\author{
Abstracta Iranica \\ Abstracta Iranica Revue bibliographique pour le domaine irano-aryen \\ Volume 32-33 | 2013 \\ Comptes rendus des publications de 2009-2010
}

\title{
N. Czechowicz, M. Dandamayev. A Late Achaemenid Document from TapsuHu
}

\section{Astrid Nunn}

\section{(2) OpenEdition}

\section{Journals}

\section{Édition électronique}

URL : http://journals.openedition.org/abstractairanica/40224

DOI : 10.4000/abstractairanica.40224

ISSN : 1961-960X

Éditeur :

CNRS (UMR 7528 Mondes iraniens et indiens), Éditions de l'IFRI

\section{Édition imprimée}

Date de publication : 1 décembre 2013

ISSN : 0240-8910

\section{Référence électronique}

Astrid Nunn, « N. Czechowicz, M. Dandamayev. A Late Achaemenid Document from Tapsuhu », Abstracta Iranica [En ligne], Volume 32-33 | 2013, document 50, mis en ligne le 01 juillet 2016, consulté le 26 septembre 2020. URL : http://journals.openedition.org/abstractairanica/40224 ; DOI : https://doi.org/ 10.4000/abstractairanica.40224

Ce document a été généré automatiquement le 26 septembre 2020.

Tous droits réservés 


\title{
N. Czechowicz, M. Dandamayev. A Late Achaemenid Document from TapsuHu
}

\author{
Astrid Nunn
}

\section{RÉFÉRENCE}

N. Czechowicz, M. Dandamayev. «A Late Achaemenid Document from TapsuHu », in : Sarah C. Melville, Alice L. Slotsky, eds., Opening the Tablet Box. Near Eastern Studies in Honor of Benjamin R. Foster. Leiden, 2010, p. 77-83.

1 La tablette dont il est question dans cet article est conservée l'Institut Oriental de l'Académie Russe des Sciences à Saint-Pétersbourg. Elle a été écrite en 406 av. J.-C. sous Darius II à TapsuHu, ville approximativement située sur le Moyen Euphrate, et traite d'une livraison de brebis pour Babylone. Les AA. résument ce que l'on sait de ce toponyme.

\section{AUTEURS}

ASTRID NUNN

Université de Munich 